\title{
UNENUMERATED CONSTITUTIONAL RIGHTS AND UNENUMERATED BIBLICAL OBLIGATIONS: A PRELIMINARY STUDY IN COMPARATIVE HERMENEUTICS
}

\author{
Samuel J. Levine*
}

\section{INTRODUCTION}

In 1986, Robert Cover wrote of an "explosion of legal scholarship placing interpretation at the crux of the enterprise of law." As examples of this phenomenon, Cover cited the works of such influential scholars as Ronald Dworkin ${ }^{2}$ and James Boyd White, ${ }^{3}$ as well as law review symposia, which, Cover noted, focused on "interpretation" or "hermeneutics." As part of the continuing emphasis on hermeneutics in constitutional interpretation, a body of literature has emerged comparing constitutional textual analysis to Biblical hermeneutics.' This scholar-

* Assistant Legal Writing Professor \& Lecturer in Jewish Law, St. John's University School of Law; LL.M. 1996, Columbia University; Ordination 1996, Yeshiva University; J.D. 1994, Fordham University; B.A. 1990, Yeshiva University. An earlier draft of this Essay received an Award in the 1997 St. John's University Vincentian Chair of Social Justice Human Rights Research Competition.

1. Robert M. Cover, Violence and the Word, 95 Yale L.J. 1601, 1601-02 n.2 (1986).

2. See Ronald Dworkin, Law's Empire (Belknap Press, 1986).

3. See James Boyd White, Heracles' Bow (U. of Wisconsin Press, 1985); James Boyd White, When Words Lose Their Meaning (U. of Chicago Press, 1984).

4. See Interpretation Symposium, 58 S. Cal. L. Rev. 1 (1985); Symposium, Law and Literature, 60 Tex. L. Rev. 373 (1982).

5. Cover, 95 Yale L.J. at 1602 n.2 (cited in note 1).

6. See, e.g., Jim Chen, Book Review, 11 Const. Comm. 599 (1994-95) (reviewing H. Jefferson Powell, The Moral Tradition of American Constitutionalism: A Theological Interpretation); Robert M. Cover, The Supreme Court, 1982 Term-Foreword: Nomos and Narrative, 97 Harv. L. Rev. 4 (1983); David R. Dow, Constitutional Midrash: The Rabbis' Solution to Professor Bickel's Problem, 29 Houston L. Rev. 543 (1992); Edward M. Gaffney, Jr., Politics Without Brackets on Religious Convictions: Michael Perry and Bruce Ackerman on Neutrality, 64 Tulane L. Rev. 1143, 1166 n.102 (1990); Thomas C. Grey, The Constitution as Scripture, 37 Stan. L. Rev. 1 (1984); Morton J. Horwitz, The Supreme Court, 1992 Term-Foreword: The Constitution of Change: Legal Fundamentality Without Fundamentalism, 107 Harv. L. Rev. 30, 48-51 \& 50 n.90 (1993); Interpretation Symposium (cited in note 4); Samuel J. Levine, Jewish Legal Theory and American Con- 
ship has been based on the recognition that, like the Constitution, the Bible functions as an authoritative legal text that must be interpreted in order to serve as the foundation for a living community.

This Essay looks at a basic hermeneutic device common to both Biblical and constitutional interpretation, the identification of unenumerated principles through reference to textually enumerated principles. The Essay observes that, in addition to the numerous obligations listed in the Torah, legal authorities have interpreted the Torah to impose many other obligations not enumerated in the text. The Essay suggests that a similar methodology to that employed in Jewish law has been applied to the United States Constitution to derive rights beyond those enumerated in the text. The Essay thus examines the ways in which American judges and constitutional scholars have relied on forms of textual analysis that find analogues in the interpretation of the Torah by Jewish legal authorities.

\section{SUBSTANTIVE DUE PROCESS AND "YOU SHALL BE HOLY"}

Despite its function as the guarantor of individual rights against infringement by the government, the United States Constitution, including the Bill of Rights, is surprisingly limited in its enumeration of substantive rights.' Nevertheless, the United States Supreme Court has consistently held that the Constitution protects a number of rights beyond those listed in the text. To support these conclusions, the Court has engaged in a variety of interpretive techniques that, to a significant extent, parallel various methods of Biblical interpretation.

In the 1923 case of Meyer v. Nebraska, ${ }^{8}$ the Supreme Court was faced with a challenge to a Nebraska state law which prohibited the teaching of "any language other than the English

stitutional Theory: Some Comparisons and Contrasts, 24 Hastings Const. L. Q. 441 (1997); Sanford Levinson, Constitutional Faith (Princeton U. Press, 1988); Lawrence B. Solum, Originalism as Transformative Politics, 63 Tulane L. Rev. 1599 (1989); Steven D. Smith, Idolatry in Constitutional Interpretation, 79 Va. L. Rev. 583 (1993).

7. In fact, as Professor Charles Black has observed, "[i]f one ... looks over th[e] canvas of textually expressed guarantees of human rights against actions of the States, one has to be impressed with their entire inadequacy, by a very wide margin, as a corpus of human-rights substantive protections that could possibly characterize any society generally as a free society by law." Charles L. Black, Jr., "One Nation Indivisible": Unnamed Human Rights in the States, 65 St. John's L. Rev. 17, 21 (1991).

8. 262 U.S. $390(1923)$. 
language" prior to high school. ${ }^{9}$ Though the text of the Constitution does not explicitly protect the right to education, the Court found that such a right is guaranteed by the Constitution, and held that the Nebraska statute violated the individual's right to pursue and select a reasonable and beneficial means of education.

In recognizing this unnamed right, the Court relied on and interpreted the Fourteenth Amendment, which guarantees that "[n]o State shall ... deprive any person of life, liberty, or property, without due process of law." Focusing on the ambiguity of the word "liberty," the Court understood the Fourteenth Amendment to protect a broad range of rights, including

[w] ithout doubt ... not merely freedom from bodily restraint but also the right of the individual to contract, to engage in any of the common occupations of life, to acquire useful knowledge, to marry, establish a home and bring up children, to worship God according to the dictates of his own conscience, and generally to enjoy those privileges long recognized at common law as essential to the orderly pursuit of happiness by free men. ${ }^{\text {II }}$

Turning to education, the Court stated that " $[\mathrm{t}] \mathrm{he}$ American people have always regarded education and acquisition of knowledge as matters of supreme importance which should be diligently promoted." 12 Therefore, the Court concluded that the teacher's "right thus to teach and the right of parents to engage him so to instruct their children ... are within the liberty of the Amendment." ${ }^{13}$ The Nebraska law violated the Constitution because it "attempted materially to interfere with the calling of modern language teachers, with the opportunities of pupils to acquire knowledge, and with the power of parents to control the education of their own." ${ }^{14}$

Two years later, in Pierce v. Society of Sisters, ${ }^{15}$ a Catholic parochial school and private military academy challenged an Oregon statute requiring children between the ages of eight and sixteen to attend public school. Relying on Meyer, the Court found it "entirely plain" that the statute "unreasonably inter-

\footnotetext{
9. Id. at 397.

10. U.S. Const., Amend. XIV, $\$ 1$.

11. Meyer, 262 U.S. at 399.

12. Id. at 400 .

13. Id.

14. Id. at 401.

15. 268 U.S. 510 (1925).
} 
feres with the liberty of parents and guardians to direct the upbringing and education of children under their control." ${ }^{\prime 6}$ Elaborating on the concept of liberty, the Court declared that

[ $\mathrm{t}$ ] he fundamental theory of liberty upon which all governments in this Union repose excludes any general power of the State to standardize its children by forcing them to accept instruction from public school teachers only.... [T] hose who nurture him and direct his destiny have the right, coupled with the high duty, to recognize and prepare him for additional obligations. ${ }^{17}$

The Court's approach in these two cases reflects a willingness to look beyond those rights enumerated in the text of the Constitution, by suggesting that additional rights are encompassed under the Fourteenth Amendment's broad guarantee of "liberty." According to the Court, the term "liberty" clearly includes a wide range of activities and privileges - such as education - that, although absent from the constitutional text, are apparently so basic to the idea of freedom as to make their enumeration unnecessary. The Court's approach, relying on what is commonly called "substantive due process," raised some criticism when applied in certain areas of the law ${ }^{18}$ but the influence of Meyer and Pierce continues to be seen in the Court's further articulation of unenumerated rights.

In the 1977 case, Moore v. City of East Cleveland, ${ }^{19}$ for example, the Court held unconstitutional a housing ordinance that prohibited a woman from living in her home with her two grandsons. In his plurality opinion, Justice Powell noted that "[a] host of cases, tracing their lineage to Meyer ... and Pierce ... have consistently acknowledged a 'private realm of family life which the state cannot enter." ${ }^{20}$ Indeed, relying on the concept of substantive due process, the opinion further observed that " $[t]$ his Court has long recognized that freedom of personal choice in matters of marriage and family life is one of the liberties protected by the Due Process Clause of the Fourteenth Amend-

16. Id. at $534-35$.

17. Id. at 535 .

18. Even those justices who have relied on substantive due process have acknowledged that "[s]ubstantive due process has at times been a treacherous field for this Court." Moore v. City of East Cleveland, 431 U.S. 494, 502 (1977) (Powell, J.).

19. 431 U.S. 494 (1977).

20. Id. at 499 (Powell, J.) (quoting Prince v. Massachusetts, 321 U.S. 158, 166 (1944)). 
ment."21 The opinion included in this area of liberty the right of a grandmother to live with her grandchildren.

As Justice Powell conceded, the right he articulated was not only absent from the text of the Constitution, but had not been identified in prior case law. In response to the criticism of the dissenters in the case, however, Justice Powell insisted that "unless we close our eyes to the basic reasons why certain rights associated with the family have been accorded shelter under the Fourteenth Amendment's Due Process Clause, we cannot avoid applying the force and rationale of these precedents to the family choice involved in this case." 22 Justice Powell quoted extensively from an earlier opinion of Justice Harlan, which explained that

the full scope of the liberty guaranteed by the Due Process Clause cannot be found in or limited by the precise terms of the specific guarantees elsewhere provided in the Constitution. This "liberty" is not a series of isolated points pricked out in terms of the taking of property; the freedom of speech, press, and religion; the right to keep and bear arms; the freedom from unreasonable searches and seizures; and so on. It is a rational continuum which, broadly speaking, includes a freedom from all substantial arbitrary impositions and purposeless restraints.

Thus, Justice Powell relied on Justice Harlan's eloquent declaration that a proper understanding of the guarantees of liberty requires looking beyond the specific rights enumerated in the Constitution, to uncover the underlying principles those rights represent. According to Justice Powell, these principles mandate protecting "the sanctity of the family precisely because the institution of the family is deeply rooted in this Nation's history and tradition." ${ }^{24} \mathrm{He}$ concluded that "[t]he tradition of ... grandparents sharing a household along with parents and children has roots equally venerable and equally deserving of constitutional recognition."

This tradition of interpreting the term "liberty" expansively parallels Jewish legal interpretation of the Torah. The Torah,

21. Id. (quoting Cleveland Board of Education v. LaFleur, 414 U.S. 632, 639-40 (1974)).

22. Id. at 501 (Powell, J.).

23. Id. at 502 (Powell, J.) (quoting Poe v. Ullman, 367 U.S. 497, $542-43$ (1961) (Harlan, J., dissenting)).

24. Id. at 503 (Powell, J.).

25. Id. at 504 (Powell, J.) 
the Five Books of Moses, is the primary source of Jewish law and religious obligations. Through the commandments, the Torah enumerates a large number of obligations and prohibitions incumbent upon both individuals and the community as a whole. In fact, according to most methods of counting, the Torah lists 613 commandments, many of which may in turn be analyzed to include more than a single obligation or prohibition. Yet, despite the large number of enumerated commandments, which provide a somewhat comprehensive guide to religious life, the text of the Torah, like the Constitution, does not detail every area of human behavior. ${ }^{26}$

Thus, just as the Constitution is understood and interpreted to protect rights that are not listed explicitly, the Biblical text is understood and interpreted to impose unenumerated religious obligations. Parallel to the Supreme Court's reliance on the concept of "liberty" found in the Fourteenth Amendment's Due Process Clause as a broad directive to guarantee unnamed rights, some Jewish legal authorities have relied on the command "you shall be holy" ${ }^{2+}$ as broadly mandating adherence to unenumerated obligations and prohibitions.

In his commentary on the Torah, Nachmanides, one of the most influential of Medieval Jewish legal scholars, discusses the use of this command as a source for unnamed obligations. Citing Talmudic sources that interpret the concept of "holiness" as involving separation from improper activities, Nachmanides observes that the Torah lists a number of activities to be avoided. ${ }^{28}$ For example, the Torah contains various dietary laws, listing foods that are not kosher and describing the manner in which kosher food must be prepared. Nachmanides notes, however, that the Torah does not enumerate all religious obligations relating to food, such as prohibitions against gluttony and drunkenness. ${ }^{29}$

Indeed, like the Constitution, which enumerates certain rights but does not mention explicitly the areas of "liberty" relating to education and family life, the Torah does not detail all

26. Robert Cover has explored the substantive difference between the American legal system's focus on rights and the Jewish legal system's focus on obligations. See Robert M. Cover, Obligation: A Jewish Jurisprudence of the Social Order, 5 J.L. \& Rel. 65 (1987). This paper focuses on the similarity in interpretive methodologies in the two systems rather than on the substantive interpretations themselves.

27. Leviticus 19:2.

28. See 2 Nachmanides, Commentary on the Torah 115-16 (Chaim Chavel, ed., Mossad Harav Kook, 1960) (commenting on Leviticus 19:2) (author's translation).

29. See id. 
aspects of "holiness." Instead, in addition to listing a number of obligations relating to the concept of "holiness," the Torah commands a general obligation to "be holy." Jewish legal authorities, whose judicial function includes interpreting the religious text, viewed the broad principle of "holiness" as an extension of those obligations found in the text, analogous to the function of the broad constitutional term "liberty" in relation to those rights found in the text of the Constitution.

Through an analysis parallel to that employed by the Court in Meyer and Pierce, and by Justice Powell in Moore, the rabbinic authorities looked to the religious tradition to define the scope of activity implicit in the command to "be holy." Thus, for example, the authorities viewed the Biblical stories describing the sinful behavior that resulted from the drunkenness of Noah and Lot as implying that drunkenness is inconsistent with holiness. Using this method, rabbinic authorities concluded that the command required abstention from various activities beyond those explicitly prohibited in the text of the Torah, that contradict the concept of holiness, including improper modes of eating, speech, dress, and sexual activity.

\section{PRIVACY, PENUMBRAS AND "YOU SHALL DO THE JUST AND THE GOOD"}

Another area in which the Supreme Court has identified constitutionally protected rights beyond those in the text is the sphere of privacy. The Court's approach in this area has been similar to its approach in identifying liberty rights, though the Court has employed a somewhat different methodology. Likewise, the Court's approach to privacy finds its parallels in Jewish religious interpretation of the command in Deuteronomy to "do the just and the good," which appears to differ slightly from the method of interpreting the command to "be holy."

The concept of a right to privacy in American law is an old one. Constitutional amendments protecting the rights of criminal defendants indicate a fundamental appreciation for an individual's privacy rights, reflected in Supreme Court decisions in the criminal procedure context. However, it was not until the 1965 case of Griswold v. Connecticut ${ }^{31}$ that the Court focused on

30. See also Maimonides, Mishne Torah, Laws of De'oth 3:2, 5:1-13 (Mossad Harav Kook, 1990); Nachmanides, 2 Commentary at $151-52$ (cited in note 28) (commenting on Leviticus 23:24).

31. 381 U.S. 479 (1965). 
a general constitutional protection of the individual's right of privacy.

In Griswold, the Court struck down as unconstitutional a state statute prohibiting the use of contraceptives. Although the Constitution obviously does not enumerate a right to use a contraceptive, or even a general right to privacy, the Court held that the rights enumerated in the Constitution should not be read as narrow or exclusive declarations of those rights that are to be protected. Instead, the Court stated, "specific guarantees in the Bill of Rights have penumbras, formed by emanations from those guarantees that help give them life and substance."32

In order to connect the concept of a "penumbra" to some of its earlier decisions, the Court focused on the "penumbra" emanating from the Free Speech Clause of the First Amendment. The Court cited cases which it understood to recognize that "the First Amendment has a penumbra where privacy is protected from governmental intrusion. ${ }^{33}$ For example, although the First Amendment does not enumerate a "freedom of association," in a 1958 case the Court had identified the "freedom to associate and privacy in one's associations" as a "peripheral First Amendment right. ${ }^{34}$ The Court in Griswold explained that "while [association] is not expressly included in the First Amendment its existence is necessary in making the express guarantees fully meaningful." ${ }^{35}$

Moreover, the Court found, other aspects of the unenumerated right to privacy emanated from other enumerated rights. According to the Court, "[v]arious guarantees create zones of privacy." ${ }^{36}$ Thus, the Court found that the Third Amendment's protection against the quartering of soldiers in a house during peacetime without the owner's consent represents "another facet of that privacy." ${ }^{37}$

Similarly, the Court had previously observed that the Fourth and Fifth Amendments' protections of criminal defendants' rights recognized the "sanctity of a man's home and the privacies of life." In fact, the Court had explicitly stated that the Fourth Amendment's prohibition against unreasonable

\footnotetext{
32. Id. at 484 .

33. Id. at 483 .

34. Id. (citing NAACP v. Alabama, 357 U.S. 449, 462 (1958)).

35. Id.

36. Id. at 484 .

37. Id.

38. Id. (quoting Boyd v. United States, 116 U.S. 616, 630 (1886)).
} 
searches and seizures created a "right to privacy, no less important than any other right carefully and particularly reserved to the people." ${ }^{39}$ Likewise, the Court in Griswold found that the Fifth Amendment's protection against self-incrimination "enables the citizen to create a zone of privacy which government may not force him to surrender to his detriment." Court pointed to the Ninth Amendment's explicit statement that "[t]he enumeration in the Constitution, of certain rights, shall not be construed to deny or disparage others retained by the people." ${ }^{, 41}$

Turning then to the Connecticut statute that prohibited the use of contraceptives, the Court described the case as "concern[ing] a relationship lying within the zone of privacy created by several fundamental constitutional guarantees." ${ }^{, 42}$ Declaring a respect for "the sacred precincts of marital bedrooms" the Court concluded that "[t]he very idea" of allowing the police to search such areas for contraceptives "is repulsive to the notions of privacy surrounding the marriage relationship."

The Court's reliance on the concept of "penumbras" in Griswold and subsequent cases was controversial. A number of Justices in Griswold either concurred in the decision but relied on other modes of analysis, or dissented outright. In his dissenting opinion, Justice Stewart, joined by Justice Black, asked rhetorically "[w]hat provision of the Constitution ... does make the state law invalid? The Court says it is the right of privacy 'created by several fundamental constitutional guarantees.' With all deference, I can find no such general right of privacy in the Bill of Rights, in any other part of the Constitution, or in any case ever before decided by this Court." ${ }^{44}$

The Court's extension of its holding in Griswold to other contexts engendered more controversy. In 1972, in Eisenstadt $v$. Baird, ${ }^{45}$ the Court struck down a Massachusetts statute prohibiting distribution of contraceptives to single persons, stating that "[i]f the right of privacy means anything, it is the right of the individual, married or single, to be free from unwarranted governmental intrusion into matters so fundamentally affecting a

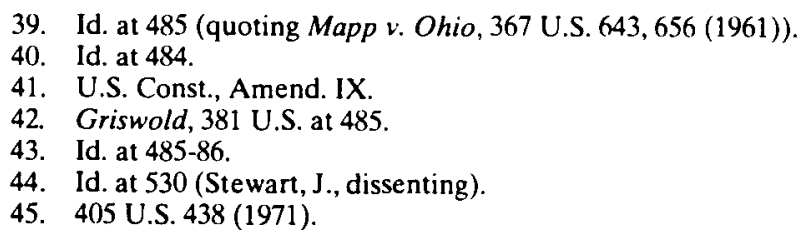


person as the decision whether to bear or beget a child." ${ }^{\text {,4 }}$ Chief Justice Burger's dissent, though it did not challenge the authority of Griswold, referred to its "tenuous moorings to the text of the Constitution." ${ }^{47}$ Additionally, the Chief Justice criticized the Court in Eisenstadt for "pass[ing] beyond the penumbras of the specific guarantees into the uncircumscribed area of personal predilections." ${ }^{\text {t8 }}$

Notwithstanding such criticisms, however, the majority of the Court prevailed in identifying unenumerated rights through an extension of the principles embodied in those rights actually enumerated in the constitutional text. The Court determined that an analysis of several amendments pointed clearly to the underlying principle of a general, more encompassing right of privacy. Similarly, in Jewish thought, in addition to those obligations articulated in the text or implied through the explicit concept of holiness, many obligations are subsumed under the more general concept of doing "the just and the good.",49

The command to "be holy" provides a textual basis for a broad obligation to refrain from activities that conflict with the concept of holiness. Yet, both the enumerated commands generally associated with "holiness" - such as eating kosher foodas well as those imperatives cited by Nachmanides and other legal authorities as examples of "holiness" and "separation"such as refraining from drunkenness - are largely restricted to one area of obligation in Jewish thought, involving the relationship between a human being and God. The other major area of obligation, though also reflecting on an individual's relationship to God, involves primarily those commandments relating to interpersonal relationships. In this area as well, although the Torah lists many commandments, these commands are not a comprehensive list of obligations. Rather, rabbinic authorities found that many unenumerated obligations are mandated by the general obligation to "do the just and the good."

Like his explanation of the command to "be holy," Nachmanides' discussion of the command to "do the just and the good" is instructive. Nachmanides again explains the reasoning behind the rabbinic interpretations, through which Jewish legal authorities derived principles of obligation in interpersonal rela-

46. Id. at 453 .

47. Id. at 472 (Burger, C.J., dissenting).

48. Id. (Burger, C.J., dissenting).

49. Deuteronomy 6:18. 
tionships beyond those enumerated in the text. Looking at the context of the command, Nachmanides notes that the previous verse commands observance of the laws "which [God] has commanded you." "il The next verse, then, describing a more general obligation to do the "just and the good," apparently refers to obligations other than and beyond those which God has expressly commanded. ${ }^{51}$ As Nachmanides further explains, the second verse is necessary because it would be impossible for the Torah to prescribe the proper mode of behavior for every situation that arises in the course of interpersonal dealings. ${ }^{52}$

Instead, according to Nachmanides, the Torah enumerates numerous obligations and prohibitions that are fundamental to the way humans should treat each other, including, among many others, respecting elders, preventing harm to others, and not seeking revenge. ${ }^{3}$ Yet, like those rights enumerated in the Constitution, these commandments all have their own penumbras, formed by emanations creating a "zone of the just and the good," analogous to a "zone of privacy." Thus, parallel to the Court in Griswold and Eisenstadt, the rabbinic authorities inferred from the nature of the enumerated laws a number of unenumerated interpersonal obligations falling within the zone of the good and the just, such as according neighbors the right of first refusal on land, dressing and speaking in a respectful manner, and behaving courteously in litigious settings. ${ }^{54}$

It should be noted that, although the phrase "the just and the good" does appear in the text of the Torah, its interpretative methodology is closer to the constitutional interpretation of "privacy" than to that of "liberty." Unlike the phrase "liberty," and, indeed, unlike the phrase "be holy," religious authorities did not point to historical definitions or traditions that would help elucidate the meaning of the words "just" and "good." Rather, using a technique more similar to the Court's approach to the broad concept of privacy that emanated from specific guarantees, religious authorities looked to the underlying principles of "just and good" behavior that emanated from enumerated interpersonal obligations, then applied those principles to situations which were not addressed in the text. Thus, just as the

50. Nachmanides, 2 Commentary at 376 (cited in note 28 ) (commenting on Deuteronomy 6:18) (citing Deuteronomy 6:17)).

51. Id.

52. See id.

53. See id. (citing Leviticus 19:16, 18, 22).

54. Id. 
Court derived constitutional rights based on the broad and unenumerated concept of privacy, Jewish legal authorities derived a range of "just" and "good" behavior not found in the Biblical text but nevertheless required by the Torah.

\section{THE NINTH AMENDMENT AND "LOVE YOUR NEIGHBOR AS YOURSELF"}

Perhaps the broadest potential source of unenumerated constitutional rights is the Ninth Amendment, which states: "The enumeration in the Constitution, of certain rights, shall not be construed to deny or disparage others retained by the people." Though the actual derivation of unenumerated human rights based on the Ninth Amendment has been controversial, on its face the Amendment clearly appears, as Justice Goldberg put it, to "show[] a belief of the Constitution's authors that fundamental rights exist that are not expressly enumerated in the first eight amendments and an intent that the list of rights included there not be deemed exhaustive." ${ }^{\text {"6 }}$

Although the Court in Griswold referred to the Ninth Amendment as one source of penumbras contributing to the zone of privacy, the majority relied primarily on other parts of the Constitution to derive a right of privacy protecting the use of contraceptives. Justice Goldberg, however, in his concurring opinion, "emphasize[d] the relevance of th[e Ninth] Amendment to the Court's holding." "F7 Focusing on both the language and the history of the Ninth Amendment, Justice Goldberg concluded that "the Framers of the Constitution believed that there are additional fundamental rights, protected from governmental infringement, which exist alongside those fundamental rights specifically mentioned in the first eight constitutional amendments. ${ }^{58}$ Indeed, Justice Goldberg argued that refusal to recognize the right of privacy in marriage because it is not mentioned explicitly in the first eight amendments "is to ignore the Ninth Amendment and give it no effect whatsoever," and, in fact "would violate the Ninth Amendment." 59

Despite the vitality of Justice Goldberg's arguments, however, his views did not prevail in Griswold and appear to have

55. U. S. Const, Amend. IX.

56. Griswold v. Connecticut, 381 U.S. 479, 492 (1964) (Goldberg, J., concurring).

57. Id. at 487 (Goldberg, J., concurring).

58. Id. at 488 (Goldberg, J., concurring).

59. Id. at 491 (Goldberg, J., concurring). 
had little influence on the Court's later decisions. Nevertheless, a number of constitutional scholars have advanced theories using the Ninth Amendment to derive unenumerated human rights. One of the most prominent and influential scholars in this endeavor has been Charles Black, whose declared aim is "the rational development of an open-edged corpus juris of humanrights constitutional law." Goldberg's, Professor Black insists that

preponderance of reason leaves us with the conclusion, about as well-supported as any we can reach in law, that the Ninth Amendment declares as a matter of law- of constitutional law, overriding other law - that some other rights are "retained by the people," and that these shall be treated as on an equal footing with rights enumerated."

Black rejects the attitude of those who find application of the Ninth Amendment unworkable because "[w]e are not told what [the unenumerated rights] are" and thus claim that "no action is possible, because you haven't been told exactly how to act." ${ }^{\prime 2}$ Instead, Black prescribes "tak[ing] the Ninth Amendment as a command to use any rational methods available to the art of law, and with these in hand to set out to discover what it is you are to protect.." ${ }^{\prime 3}$ In particular, Black envisions a constitutional imperative that would require "a radical redirection of theory and practice toward wiping out poverty."

To arrive at his view of a "constitutional justice of livelihood," Black suggests that the Ninth Amendment "command[s] us to use the methods available within our legal system in an ongoing search for 'unenumerated' rights." ${ }^{65}$ As a means for identifying those rights, Black looks to the Declaration of Independence. Turning specifically to poverty and its effect on "Life, Liberty, and the pursuit of Happiness," Black writes hauntingly that

many people do die, quickly sometimes, sometimes more

60. Charles L. Black, Jr., On Reading and Using the Ninth Amendment, in Power

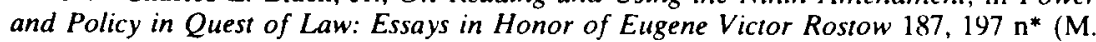
McDougal \& W.M. Reisman, eds., Martinos Nijhoff, 1985).

61. Id. at 188 .

62. Id. at $188-89$.

63. Id. at 189 .

64. Charles L. Black, Jr., On Worrying About the Constitution, 55 U. Colo. L. Rev. 469,471 (1984).

65. Charles L. Black. Jr., Further Reflections on the Constitutional Justice of Livelihood, 86 Colum. L. Rev. 1103,1104 (1986). 
slowly, of poverty; poverty may be the leading cause of death. Liberty is very often made into a mocking simulacrum by poverty. But I would lay strongest stress on the phrase, "the pursuit of happiness." ... The possession of a decent material basis for life is an indispensable condition, to almost all people and at almost all times, to this "pursuit." The lack of this basis - the thing we call "poverty"-is overwhelmingly, in the whole human world, the commonest, the grimmest, the stubbornest obstacle we know to the pursuit of happiness. I have suggested that poverty may be the leading cause of death; it is pretty certain that it is the leading cause, at least among material causes, of despair in life.... [T] he right to the pursuit of happiness is going to be, for all but a small minority of those in poverty, the palest grinning ghost of a right. ${ }^{66}$

Black also responds to those who would oppose his arguments in favor of a constitutional justice of livelihood by asking "How much?" or "Where do you draw the line?" Focusing on the evils of poverty, Black writes powerfully that

[w] hen we are faced with these difficulties of "how much," it is often helpful to step back and think small, and to ask not, "What is the whole extent of what we are bound to do?" but rather, "What is the clearest thing we ought to do first?" When we descend to that level, one reasonable answer occurs. Somebody's count [in 1985] is that a million and a half people in the State of New York are undernourished; somebody else's count is that $13 \%$ of the American people live in poverty, which pretty much always implies hunger more or less serious. This hunger is disproportionately high among children; about half our black children under six lived in poverty in 1984. Some helpless old people eat dog food when they can get it .... Now you can bog down in a discussion about the exact perimeter of "decent livelihood," or you can cease for a moment from that commonly diversionary tactic and note that, wherever the penumbra may be, malnourished people are not enjoying a decent livelihood. ${ }^{67}$

While Black's eloquent testimony about poverty may make academic any questions about where to draw the line in guaranteeing a justice of livelihood, his critics do express a valid concern for the need to identify limits to the obligations that are implied by the Ninth Amendment. Even an open-ended corpus of human rights must acknowledge that not all imagined rights can

66. Id. at $1105-06$.

67. Id. at 1114-15 (footnotes omitted). 
be guaranteed by the Constitution. There must be some lines drawn and limitations recognized in what can be expected and required of society. Nevertheless, these considerations do not invalidate Black's call for an acceptance of the Ninth Amendment as a general command to discover and protect unenumerated human rights. In fact, a possible parallel to his approach may be found in the Biblical command to "Love your neighbor as yourself."

Together with enumerated commandments dealing with interpersonal relationships and the commandment to do the "just" and the "good," the Torah contains a broad commandment governing interpersonal conduct, "Love your neighbor as yourself." Parallel to the Ninth Amendment in Professor Black's system, this commandment is understood by Jewish religious authorities to clearly indicate that, in addition to the interpersonal obligations listed in the Biblical text, there are other obligations incumbent on an individual to comply with loving one's neighbor as one's self. Moreover, just as Black emphasized that he considered his interpretation of the Ninth Amendment to be grounded in a basic analysis of American constitutional law, the Talmudic sage Rabbi Akiva emphasized the significance of the command to "love your neighbor" in Jewish Law, referring to it as "a fundamental principle in the Torah."

Perhaps the most striking similarity between the commandment to "love your neighbor" and the Ninth Amendment is the broad language used in both phrases. It is the broad reference to "other [rights] retained by the people" that leads Black to consider the Ninth Amendment to be the basis for "the rational development of an open-edged corpus juris of humanrights constitutional law." gation to search for and discover unenumerated human rights that the Constitution protects.

Likewise, the broad language of the phrase "love your neighbor as yourself" implies an obligation to identify unenumerated obligations that would express loving one's neighbor as one's self, and then to treat others as one would wish to be treated. Indeed, in his Code of Law, Maimonides cites Talmudic sources which list some examples of conduct required by the

68. Leviticus 19:18.

69. See Rashi, Commentary on the Torah (commenting on Leviticus 19:18) (quoting Torath Kohanim).

70. U.S. Const., Amend. IX.

71. Black, On Reading and Using the Ninth Amendment (cited in note 60). 
command, including speaking words of praise for others and being concerned for the monetary welfare of others, just as one would seek one's own honor and be concerned for one's own financial well-being. ${ }^{72}$ Emphasizing the importance of these principles, Maimonides quotes the Talmudic statement that "one who gains honor through disgracing another has no place in the World to Come." 73

Despite the broad obligation to love one's neighbor as one's self, though, the commandment has one more element in common with the Ninth Amendment. Although the Ninth Amendment, according to Black and others, mandates the identification of a wide range of human rights not enumerated in the constitutional text, there are limits on what rights society will recognize and protect. Likewise, there are limits to the conduct required as part of loving one's neighbor as one's self. For example, as Nachmanides notes in his Biblical commentary, the Talmud concludes that preserving one's own life takes precedence over preserving the life of another. ${ }^{74}$ Indeed, on a more general level, Nachmanides suggests that the Torah's commandment to love others as one's self should be understood more in the nature of a goal than an actual requirement, because he finds it psychologically unfeasible that the Torah would obligate individuals truly to love others to the same degree as they love themselves.' Thus, a final similarity between the Ninth Amendment and this commandment appears to be that, although there are limits on the scope of each principle, an honest evaluation of human nature suggests that the more relevant question in each case is usually not going to be "How much?" but rather "where do we start?"

\section{CONCLUSION}

In 1987, Professor William Wagner wrote of the "apparent crisis that has emerged in the Nation's understanding of civil rights law" which prompted the Columbus School of Law, Catholic University, to conduct a symposium addressing the relationship between religion and human rights. ${ }^{76}$ The symposium

72. See Maimonides, Laws of De'oth at 6:3 (cited in note 30).

73. Id.

74. Nachmanides, Commentary on the Torah at 119 (cited in note 28) (commenting on Leviticus 19:17).

75. See id.

76. See William Joseph Wagner, Reflections on the Symposium: An Ordered Inquiry Into the Relation of Civil Rights Law and Religion, 5 J.L. \& Rel. 5 (1987). 
produced a variety of illuminating papers and discussions identifying a religious basis for human rights. At the same time, however, Professor Wagner acknowledged that the symposium was founded upon certain presuppositions, two of which, in particular, are not shared by all legal theorists. One presupposition, "that the law's meaning and validity requires grounding in an extralegal source," apparently contradicts positivist viewpoints." The symposium's "further presupposi[tion] that religion can serve, if only in some attenuated sense, as such a source of meaning and validity," contradicts the view that "religion is in principle not suited to this role, e.g., the position that religion is a private preference unrelated to the public meaning of civil rights."

To the extent that these two presuppositions remain controversial among legal theorists, despite its significance, the symposium was inevitably limited in the influence it was able to exert on legal discourse. The aim of this Essay is to carry forward the pursuit of advancing the discussion of human rights through an examination of religious texts, while avoiding the controversial elements of the approach propounded at the symposium. Toward that end, the Essay looks to a religious text, the Torah, not as a substantive source of human rights law, but instead as a model of an authoritative legal text that must be interpreted to serve as a foundation for a living community. In so doing, the Essay builds on the work of several prominent American legal scholars who have compared constitutional textual analysis to Biblical hermeneutics. Thus, while the approach offered in this Essay may raise questions of its own, the emphasis on textual analysis rather than on substantive law adds a new dimension to the discussion of the relationship between religion and human rights, through a method that may prove to be more acceptable among legal theorists. 